\title{
FAKTOR-FAKTOR YANG BERPENGARUH TERHADAP PENGAMBILAN NILAI PEMBIAYAAN MURÂBA
}

\author{
Nina Rusydiana \& AM Hasan Ali*
}

\begin{abstract}
Factors that Influence the Decision Value of Murâbahah. In economic aspect, the existence of home industry gives substantial impact on the economy of a village. Tofu is one is potential household scale industries developed in Indonesia. In running their business, the producers also has disadvantages like the availability of sufficient capital to balanced the ability to repay the loan in accordance with its characteristics. One solution to solve this is by giving murâbahah finance. Reseach refeals that the factors that influence the decision value murâbahah financing to tofu iwul producers are value of installments, number of installments, the amount of the worker and the capital value of the coefficient of determination value contribution is 0.705 .
\end{abstract}

Keywords: murâbahah, home industry, capital

Abstrak: Faktor-faktor yang Berpengaruh terhadap Pengambilan Nilai Pembiayaan Murâbahah. Keberadaan industri rumah tangga memberikan dampak yang cukup besar bagi perekonomian di suatu desa. Salah satu industri skala rumah tangga yang potensial dikembangkan di Indonesia adalah pengolahan tahu. Salah satu kendalah para produsen tahu dalam menjalankan usahanya ialah adalah ketidaktersediaan modal yang cukup. Salah satu solusi atas permasalahan tersebut adalah dengan menyalurkan pembiayaan murâbahah. Hasil penelitian menunjukkan bahwa faktorfaktor yang berpegaruh dalam pengambilan nilai pembiayaan murâbahah kepada produsen tahu iwul yang berupa nilai pembiayaan murâbahah, nilai angsuran, jumlah angsuran, jumlah tanggungan pekerja, dan nilai modal memberikan nilai kontribusi koefisien determinasi sebesar 0,705.

Kata Kunci: murâbahah, industri rumah tangga, modal

Naskah diterima: 6 Juni 2011, direvisi: 7 September 2011, disetujui: 15 September 2011.

* Fakultas Sains dan Teknologi UIN Syarif Hidayatullah Jakarta. Jl. Ir. H. Juanda No. 95, Ciputat, Jakarta. E-mail: nina.rusydiana09@yahoo.com; Fakultas Syariah dan Hukum UIN Syarif Hidayatullah Jakarta. Jl. Ir. H. Juanda No. 95, Ciputat, Jakarta. E-mail: m_hasan_ali@yahoo.com 


\section{Pendahuluan}

Peranan industri kecil terhadap roda perekonomian suatu negara sangatlah besar. Di Indonesia, 99 persen dari total unit usaha berupa unit usaha kecil. Sayangnya, kontribusi terhadap produk domestik bruto (PDB) baru 14 persen. Potensi ini menjadi tantangan para pengusaha kecil untuk meningkatkan usahanya. Cukup banyak usaha kecil yang dapat dikembangkan di Indonesia, salah satu usaha kecil yang potensial untuk dikembangkan adalah usaha pengolahan tahu. ${ }^{1}$

Untuk meningkatkan produktivitas, salah satu faktor penunjang yang paling penting adalah ketersediaan modal yang cukup. Kendala permodalan tersebut, tidak mampu dipenuhi oleh perbankan modern. Hal ini dikarenakan usaha mereka dianggap tidak bankable, karena tidak adanya agunan yang miliki. Agunan adalah jaminan pembiayaan baik yang bersifat material maupun nonmaterial yang digunakan untuk memberikan keyakinan atas kemampuan dan kesanggupan debitur untuk melunasi pembiayaannya. ${ }^{2}$

Menurut Nadratuzzaman Hosen, pembiayaan atas prinsip jual-beli cocok bagi nasabah yang membutuhkan tambahan aset, namun memiliki kekurangan dana dalam upaya melunasinya secara sekaligus ${ }^{3}$. Artikel ini mencoba membahas tentang faktor-faktor yang berpengaruh terhadap pengambilan nilai pembiayaan murâbahah.

\section{Konsep Jual Beli (Sale \& Purchase)}

Jual beli berasal dari kata al-bay' artinya menjual, mengganti, dan menukar (sesuatu dengan sesuatu yang lain). Kata al-bay' dalam bahasa Arab terkadang digunakan untuk pengertian lawannya, yakni kata asy-syira' (beli). Dengan demikian maka kata al-bay' berarti "jual", tetap sekaligus juga berarti "beli" . ${ }^{4}$ Menurut Kementerian Koperasi dan Usaha Kecil Menengah, jual beli adalah proses pemindahan hak milik barang atau aset lainnya dengan mempergunakan uang sebagai medium ${ }^{5}$.

'Sarwono S dan Yan Pieter Saragih, Membuat Aneka Tahu, (Jakarta: Penebar Swadaya, 2001), h. 5 .

${ }^{2}$ Kementerian Koperasi dan Usaha Kecil Menengah, Modul Diklat Berbasis Kompetensi KJKS/UJKS Pola Syariah, (Jakarta: KUKM, 2006), h. 223.

${ }^{3}$ Nadratuzzaman Hosen, dkk, Buku Saku Lembaga Bisnis Syariah, (Jakarta: Kecana, 2006), h. 8.

${ }^{4}$ Abdul Aziz Dahlan, Ensiklopedi Hukum Islam 3, (Jakarta: PT. Ichtiar Baru Van Hoeve, 1997), h. 827.

${ }^{5}$ Kementerian Koperasi dan Usaha Kecil Menengah, Modul Diklat Berbasis Kompetensi KJKS/UJKS Pola Syariah, (Jakarta: KUKM, 2006), h. 78. 
Bay’ al-murâbahah adalah prinsip bay' (jual beli) di mana harga jualnya terdiri atas harga pokok barang ditambah nilai keuntungan (ribh) yang disepakati. Pada murâbahah, penyerahan barang dilakukan pada saat transaksi sementara pembayarannya dilakukan secara tunai, ditangguhkan ataupun dicicil. Adapun rukn (persyaratan yang harus dipenuhi agar menjadi sah) dalam jual beli adalah sebagai berikut: (1) penjual (bay'), (2) pembeli (musytarî), (3) barang/ objek (mabî̀), dan (4) ijab kabul (sighah). ${ }^{6}$

\section{Konsep al-Murâbahah}

Pembiayaan murâbahah adalah perjanjian jual beli antara bank dan nasabah di mana bank syariah membeli barang yang diperlukan oleh nasabah dan kemudian menjualnya kepada nasabah yang bersangkutan sebesar harga perolehan ditambah dengan margin/keuntungan yang disepakati antara bank syariah dan nasabah. ${ }^{7}$

Menurut Antonio Antonio, bay‘ al-murâbahah adalah jual beli barang pada harga asal dengan tambahan keuntungan yang disepakati. Dalam bay` al-murâbahah, penjual harus memberitahu harga pokok yang ia beli dan menentukan suatu tingkat keuntungan sebagai tambahannya. ${ }^{8}$ Sementara Adiwarman Karim berpendapat bahwa murâbahah adalah akad jual-beli barang dengan menyatakan harga perolehan dan keuntungan (margin) yang disepakati oleh penjual dan pembeli. ${ }^{9}$

Pendapat lain dikemukakan Yusuf dan Junaedi, pembiayaan murâbahah adalah perjanjian yang disepakati antara bank dengan nasabah, di mana bank menyediakan pembiayaan untuk pembelian bahan baku atau modal kerja lainnya yang dibutuhkan nasabah, yang akan dibayar kembali oleh nasabah sebesar harga jual bank (harga beli bank ditambah margin keuntungan) pada saat jatuh tempo. ${ }^{10}$

Hartati (2005), dalam penelitian yang berjudul "Pengaruh Pembiayaan Terhadap Pertumbuhan, Laba dan Aset Nasabah (Studi Kasus Pembiayaan Murâ-

${ }^{6}$ Sunarti Zulkifli, Panduan Praktis Transaksi Perbankan Syariah, (Jakarta: Zikrul Hakim, 2003), h. 38-39.

${ }^{7}$ Muhammad, Manajemen Pembiayaan Bank Syariah, (Yogyakarta: UPP AMP YKPN, 2000), h. 23.

${ }^{8}$ Muhammad Syafi'i Antonio, Bank Syariah dari Teori ke Praktik, (Jakarta: Gema Insani Press bekerjasama dengan Tazkia Cendikia, 2001), h. 164.

${ }^{9}$ Adiwarman Karim, Bank Islam Analisis Fiqih dan Keuangan, (Jakarta: IIIT Indonesia, 2003), h. 161 .

${ }^{10}$ Muhammad Yusuf dan Junaedi, Pengantar Ilmu Ekonomi \& Perbankan Syariah, (Jakarta: Ganeca Press, 2006), h. 69. 
bahah di PT BPRS Amanah Ummah Kecamatan Leuwiliang Kabupaten Bogor)" menyatakan bahwa pembiayaan murâbahah memberikan dampak perbedaan laba dan aset yang signifikan bagi nasabah. Hal ini terbukti dari rata-rata hitung laba dan aset sebelum dan sesudah mendapatkan pembiayaan murabahah mengalami peningkatan dari sebelumnya sebesar Rp 113.256.666,67 menjadi Rp 178.660.000,00.

Penelitian yang dilakukan oleh Rora Farida (2007) dalam "Analisis Penilaian dan Faktor-Faktor Penyaluran Pembiayaan Syariah dalam Pembiayaan Agribisnis pada BMT Khidmatul Ummah", menyatakan bahwa skim murâbahhah merupakan skim pembiayaan yang paling besar disalurkan.

\section{Analisis Regresi Berganda}

Menurut Sugiyanto, analisis regresi berganda digunakan untuk menganalisis pengaruh lebih dari satu variabel independen terhadap variabel dependen. ${ }^{11}$ Menurut Priyatno, Uji F digunakan untuk mengetahui apakah variabel independen $\left(X_{1}, X_{2}, \ldots X_{n}\right)$ secara bersama-sama berpengaruh secara signifikan terhadap variabel dependen ( $\mathrm{Y}$ ). Sedangkan uji t digunakan untuk mengetahui apakah dalam model regresi variabel independen $\left(\mathrm{X}_{1}, \mathrm{X}_{2}, \ldots \mathrm{X}_{\mathrm{n}}\right)$ secara parsial berpengaruh signifikan terhadap variabel dependen (Y). Adapun analisis determinasi $\left(\mathrm{R}^{2}\right)$ digunakan untuk mengetahui persentase sumbangan pengaruh variabel independen $\left(\mathrm{X}_{1}, \mathrm{X}_{2}, \ldots \mathrm{X}_{\mathrm{n}}\right)$ secara serentak terhadap variabel dependen (Y). ${ }^{12}$

Analisis multiregresi adalah suatu metode untuk mengkaji akibat-akibat dan besarnya akibat dari lebih dari satu variabel bebas terhadap satu variabel terikat, dengan menggunakan prinsip-prinsip korelasi dan regresi. ${ }^{13}$ Sedangkan Sugiyono berpendapat bahwa analisis regresi ganda digunakan oleh peneliti, bila peneliti bermaksud meramalkan bagaimana keadaan (naik turunnya) variabel dependen (kriterium), bila dua atau lebih variabel independen sebagai faktor predictor dimanipulasi (dinaikturunkan nilainya). Jadi, analisis regresi ganda akan dilakukan bila jumlah variabel independennya minimal $2 .{ }^{14}$

\footnotetext{
${ }^{11}$ Sugiyanto, Analisis Statistika Sosial, (Malang: Bayu Media Anggota IKAPI Jaktim, 2004), h. 195.

${ }^{12}$ Dwi Priyanto, Paham Analisa Statistik Data dengan SPSS, (Jakarta: MediaKom, 2010), h. 6668.

${ }^{13}$ Fred N Kerlinger, Asas-Asas Penelitian Behavioral, (Yogyakarta: Gadjah Mada University Press, 2006), h. 292.

${ }^{14}$ Sugiyono, Metode Penelitian Administrasi dilengkapi dengan Metode R\&D, (Bandung: Alfabeta, 2007), h. 243.
} 
Selanjutnya Nazir, menjelaskan jika parameter dari suatu hubungan fungsional antara satu variabel dependen dengan lebih dari satu variabel ingin diestimasikan, maka analisis regresi yang dikerjakan berkenaan dengan regresi berganda (multiple regression). ${ }^{15}$

\section{Metodologi}

Penelitian ini dilakukan di Kampung Iwul, Desa Bojong Sempu, Kecamatan Parung, Kota Bogor. Teknik pengambilan sampel yang digunakan adalah total sampling bertujuan (pusposive sampling), yaitu seluruh populasi yang mengambil pembiayaan murabahah sebanyak 82 orang, penelitian dilakukan pada Agustus-Oktober 2007. Penelitian ini dilakukan dengan menggunakan pendekatan kuantitatif, dengan analisis regresi berganda yang diolah dengan alat bantu SPSS 11.5.

\section{Diskusi dan Analisis}

Metode pengumpulan data yang digunakan untuk mengetahui proses pembiayaan murâbahah antara ISM dengan Produsen Tahu Iwul dilakukan dengan teknik wawancara kepada pihak pengelola ISM dan MM. Untuk mengetahui faktor-faktor yang diduga berpengaruh terhadap nilai pembiayaan murâbahah, dilakukan dengan mewawancarai beberapa produsen tahu iwul. Sedangkan untuk menganalisis pengaruh faktor nilai pembiayaan murâbahah, nilai angsuran, jumlah angsuran, jumlah tanggungan pekerja dan nilai modal, dianalisis dengan menggunakan analisis regresi berganda. Hasil dan pembahasan pada penelitian ini, untuk lebih lengkapnya dapat dilihat pada data-data berikut ini.

Pertama, proses pembiayaan murâbahah antara ISM dengan produsen tahu iwul. Konsep pembiayaan di produsen tahu iwul adalah murâbahah yang didahului dengan akad wakâlah. Proses pembiayaan murâbahah antara ISM dengan produsen tahu iwul sangat sederhana, terdiri atas dua bagian, yakni prosedur pembiayaan dan penyaluran pembiayaan.

Dalam teknis prosedur pembiayaan murâbahah, persyaratan awal yang harus dimiliki oleh produsen tahu iwul (sebagai mitra usaha) tidaklah sulit. Dalam menyalurkan pembiayaan murâbahah kepada produsen tahu iwul, ISM juga tidak banyak memberikan persyaratan. Bagi ISM, kelayakan IRT tahu iwul untuk dibiayai dilihat dari jaminan pasarnya dan kedisiplinan para mitra selama akad murâbahah diterapkan.

${ }^{15}$ Nazir, Metode Penelitian, (Jakarta: Ghalia Indonesia, 2009), h. 463. 
Kedua, faktor-faktor yang berpengaruh terhadap pengambilan nilai pembiayaan murâbahah. Berdasarkan hasil penelitian, diperoleh empat faktor yang berpengaruh terhadap pengambilan nilai pembiayaan murâbahah di produsen tahu iwul. Keempat faktor tersebut antara lain: (1) Nilai angsuran (rupiah). Adalah sejumlah rupiah tertentu yang dibayar oleh produsen tahu iwul kepada ISM dalam mengangsur pembiayaan sampai dengan melunasi pembiayaan yang telah disepakati bersama. (2) Jumlah angsuran (kali). Adalah banyaknya jumlah selang waktu dalam mengangsur pembiayaan dalam jangka waktu tertentu. (3) Jumlah tanggungan pekerja (orang). Merupakan banyaknya jumlah pekerja yang ditanggung oleh produsen tahu iwul dalam memproduksi tahu, baik anggota keluarga sendiri maupun orang lain yang menjadi beban tanggungan. (4) Nilai modal (rupiah). Adalah besarnya jumlah modal usaha yang telah dikeluarkan oleh produsen tahu iwul dalam memproduksi tahu. Keempat faktor tersebut merupakan variabel bebas yang diperoleh melalui hasil wawancara dengan produsen tahu iwul dan pendamping, sehingga pengambilan variabel bebas sudah disesuaikan dengan kondisi tempat penelitian.

Ketiga, pengaruh nilai angsuran, jumlah angsuran, jumlah tanggungan pekerja, dan nilai modal terhadap pengambilan nilai pembiayaan murâbahah. Berikut ini hasil analisis regresi berganda dari faktor nilai pembiayaan murâbahah, nilai angsuran, jumlah angsuran, jumlah tanggungan pekerja dan nilai modal, dapat dilihat pada tabel 1, sebagai berikut:

Tabel 1

Hasil Analisis Berganda: Faktor-Faktor yang Diduga Berpengaruh terhadap Pengambilan Nilai Pembiayaan Murabahah

\begin{tabular}{llccc}
\hline No & \multicolumn{1}{c}{ Faktor } & Koefisien regresi & $\mathrm{T}_{\text {hitung }}$ & Signifikansi \\
\hline 1. & Nilai angsuran & 33,769 & 9,503 & 0,000 \\
\hline 2. & Jumlah angsuran & $30.085,391$ & 3,357 & 0,001 \\
\hline 3. & $\begin{array}{l}\text { Jumlah tanggungan } \\
\text { pekerja }\end{array}$ & $37.837,306$ & 2,403 & 0,019 \\
\hline 4. & Nilai modal & 0,188 & 2,724 & 0,008 \\
\hline & $\quad$ Konstanta & $-1,475.835$ \\
& $\mathrm{~T}_{\text {tabel }}$ & 1,66 & \\
\hline
\end{tabular}

Berdasarkan tabel tersebut, maka persamaan regresi berganda untuk faktor-faktor yang berpengaruh terhadap pengambilan nilai pembiayaan murâbahah adalah sebagai berikut:

$$
Y=-1,475.835+33,769 X_{1}+30.085,391 X_{2}+37.837,306 X_{3}+0,188 X_{4}
$$




\section{Pengujian Parameter Regresi secara Tunggal (Uji-t)}

Pertama, pengujian nilai angsuran $\left(\mathrm{X}_{1}\right)$ terhadap pengambilan nilai pembiayaan murâbahah (Y). Berdasarkan hasil perhitungan olah SPSS 11.5 dengan $\alpha$ $=5 \%$ (pada tabel 1), nilai $\mathrm{t}_{\text {hitung }}$ untuk nilai angsuran adalah sebesar 9,503 $>\mathrm{t}_{\text {tabel }}$ $=1,66$ atau nilai signifikansi untuk jumlah angsuran sebesar $0,000<\alpha=0,05$. Dengan demikian, disimpulkan bahwa Ho ditolak ( $\mathrm{t}_{\text {hitung }}>\mathrm{t}_{\text {tabel }}$; sig $<\alpha$ ), yang berarti bahwa nilai angsuran memiliki pengaruh yang nyata atau signifikan secara statistik terhadap pengambilan nilai pembiayaan murâbahah di produsen tahu iwul.

Kedua, pengujian jumlah angsuran $\left(\mathrm{X}_{2}\right)$ terhadap pengambilan nilai pembiayaan murâbahah (Y). Berdasarkan hasil perhitungan olah SPSS 11.5 dengan $\alpha=5 \%$ (pada tabel 1), nilai $t_{\text {hitung }}$ untuk jumlah angsuran adalah sebesar $3,357>\mathrm{t}_{\text {tabel }}=1,66$ atau nilai signifikansi untuk jumlah angsuran sebesar 0,001< $\alpha=0,05$. Dengan demikian disimpulkan bahwa Ho ditolak $\left(\mathrm{t}_{\text {hitung }}>\mathrm{t}_{\text {tabel }} ; \operatorname{sig}<\alpha\right.$ ), yang berarti bahwa jumlah angsuran memiliki pengaruh yang nyata atau signifikan secara statistik terhadap pengambilan nilai pembiayaan murâbahah di produsen tahu iwul.

Ketiga, pengujian jumlah tanggungan pekerja $\left(\mathrm{X}_{3}\right)$ terhadap pengambilan nilai pembiayaan murâbahah (Y). Berdasarkan hasil perhitungan olah SPSS 11.5 dengan $\alpha=5 \%$ (pada tabel 1), nilai $\mathrm{t}_{\text {hitung }}$ untuk jumlah tanggungan pekerja adalah sebesar 2,403 $>\mathrm{t}_{\text {tabel }}=1,66$ atau nilai signifikansi untuk jumlah tanggungan pekerja sebesar $0,019<\alpha=0,05$. Dengan demikian dapat disimpulkan bahwa Ho ditolak ( $\mathrm{t}_{\text {hitung }}>\mathrm{t}_{\text {tabel }} ;$ sig $<\alpha$ ), yang berarti bahwa jumlah tanggungan pekerja memiliki pengaruh yang nyata atau signifikan secara statistik terhadap pengambilan nilai pembiayaan murâbahhah di produsen tahu iwul.

Keempat, pengujian nilai modal $\left(\mathrm{X}_{4}\right)$ terhadap pengambilan nilai pembiayaan murâbahah (Y). Berdasarkan hasil perhitungan olah SPSS 11.5 dengan $\alpha=5 \%$ (pada tabel 1), nilai $t_{\text {hitung }}$ untuk nilai modal adalah sebesar 2,724> $\mathrm{t}_{\text {tabel }}=1,66$ atau nilai signifikansi untuk nilai modal sebesar $0,008<\alpha=0,05$. Dengan demikian dapat disimpulkan bahwa Ho ditolak ( $\mathrm{t}_{\text {hitung }}>\mathrm{t}_{\text {tabel }} ; \operatorname{sig}<\alpha$ ), yang berarti bahwa nilai modal memiliki pengaruh yang nyata atau signifikan secara statistik terhadap pengambilan nilai pembiayaan murâbahah di produsen tahu iwul.

\section{Uji Signifikansi Simultan (Uji Statistik F)}

Uji F digunakan untuk menunjukkan apakah semua variabel bebas (nilai angsuran, jumlah angsuran, jumlah tanggungan pekerja, dan nilai modal) yang 
dimasukkan dalam model mempunyai pengaruh secara bersama-sama terhadap pengambilan nilai pembiayaan murâbahah di produsen tahu iwul.

Tabel 2

Uji Signifikansi Simultan

\begin{tabular}{lllllll}
\hline \multicolumn{1}{c}{ Model } & Sum of Squares & Df & Mean Square & $\mathrm{F}_{\text {hitung }}$ & $\mathrm{F}_{\text {tabel }}$ & Sig \\
\hline Regression & $1.62 \mathrm{E}+12$ & 4 & $4.0473 \mathrm{E}+11$ & 45.912 & 2.50 & $.000^{\mathrm{a}}$ \\
Residual & $6.79 \mathrm{E}+11$ & 77 & 8815359231 & & & \\
Total & $2.30 \mathrm{E}+12$ & 81 & & & & \\
\hline
\end{tabular}

Ket.: Predicted Interval 95\%

Berdasarkan hasil perhitungan uji $\mathrm{F}$, dengan tingkat kepercayaan 95\%, diperoleh nilai $\mathrm{F}_{\text {hitung }}$ sebesar 45,912 $>\mathrm{F}_{\text {tabel }}=2,50$ dengan nilai signifikansi $=0,000$ $<\alpha=0,05$. Dengan demikian dapat ditarik kesimpulan bahwa Ho ditolak ( $F_{\text {hitung }}$ $>\mathrm{F}_{\text {tabel }} ;$ Sig $<\alpha$ ), artinya model regresi bisa dipakai untuk memprediksi pengambilan nilai pembiayaan murâbahah. Atau bisa dikatakan, nilai angsuran, jumlah angsuran, jumlah tanggungan pekerja dan nilai modal secara bersamasama berpengaruh secara statistik terhadap pengambilan nilai pembiayaan $m u-$ râbahah.

\section{Uji Koefisien Determinasi $\left(R^{2}\right)$}

Uji koefisien determinasi $\left(\mathrm{R}^{2}\right)$ digunakan untuk melihat seberapa besar nilai angsuran, jumlah angsuran, jumlah tanggungan pekerja dan nilai modal dalam menjelaskan pengambilan nilai pembiayaan murâbahah. Berdasarkan hasil pengujian koefisien determinasi, diperoleh nilai $\mathrm{R}^{2}$ sebesar 0,705 . Artinya 70,5\% dari variansi nilai pembiayaan murâbahah mampu dijelaskan oleh faktorfaktor seperti nilai angsuran, jumlah angsuran, jumlah tanggungan pekerja dan nilai modal. Sedangkan sisanya sebesar 29,5\% dijelaskan oleh faktor lain di luar penelitian ini seperti pendapatan usaha, produktivitas usaha, jaminan usaha, dan ketersediaan bahan baku serta besarnya kesepakatan selisih keuntungan (margin).

\section{Penutup}

Proses pembiayaan murâbahah antara ISM dengan produsen tahu iwul diawali dengan akad wakâlah. Proses pembiayaan murâbahah yang dilakukan tidaklah sulit, terdiri atas dua tahapan, yaitu prosedur pembiayaan dan penyaluran pembiayaan murâbahah. Adapun faktor-faktor yang berpengaruh terhadap pengambilan nilai pembiayaan murâbahah antara lain: nilai angsuran, jumlah 
angsuran, jumlah tanggungan pekerja, dan nilai modal. Besarnya faktor-faktor nilai angsuran, jumlah angsuran, jumlah tanggungan pekerja, dan nilai modal yang berpengaruh terhadap pengambilan nilai pembiayaan murâbahah kepada produsen tahu iwul adalah sebesar 0.705. Artinya, 70,5\% dari variansi nilai pembiayaan murâbahah mampu dijelaskan oleh faktor-faktor, seperti: nilai angsuran, jumlah angsuran, jumlah tanggungan pekerja, dan nilai modal. []

\section{Pustaka Acuan}

Antonio, Muhammad Syafi'i, Bank Syariah dari Teori ke Praktik, Jakarta: Gema Insani Press bekerjasama dengan Tazkia Cendikia, 2001.

Dahlan, Abdul Aziz, Ensiklopedi Hukum Islam 3, Jakarta: PT. Ichtiar Baru Van Hoeve, 1997.

Farida, Rora, "Analisis Penilaian dan Faktor-Faktor Penyaluran Pembiayaan Syariah dalam Pembiayaan Agribisnis pada KBMT Khidmatul Ummah". Fakultas Pertanian, Bogor: Institut Pertanian Bogor, 2007.

Hartati, Sri, "Pengaruh Pembiayaan Terhadap Pertumbuhan Penjualan, Laba dan Aset Nasabah (Studi Kasus Pembiayaan Murabahah di PT. BPRS Amanah Ummah Kecamatan Leuwiliang, Kabupaten Bogor)." Fakultas Ekonomi dan Manajemen, Bogor: Institut Pertanian Bogor, 2005.

Hosen, Nadratuzzaman, dkk., Buku Saku Lembaga Bisnis Syariah, Jakarta: Kencana, 2006.

Karim, Adiwarman, Bank Islam Analisis Fiqih dan Keuangan, Jakarta: IIIT Indonesia, 2003.

Kementerian Koperasi dan Usaha Kecil Menengah, Modul Diklat Berbasis Kompetensi KJKS/UJKS Pola Syariah, Jakarta: KUKM, 2006.

Kerlinger, Fred N, Asas-Asas Penelitian Behavioral, Yogyakarta: Gadjah Mada University Press, 2006.

Muhammad, Manajemen Pembiayaan Bank Syariah, Yogyakarta: UPP AMP YKPN, 2002.

Nazir, Metode Penelitian, Jakarta: Ghalia Indonesia, 2009.

Priyatno, Dwi, Paham Analisa Statistik Data dengan SPSS, Jakarta: MediaKom, 2010.

Muhammad, Manajemen Baitul Maal Wa Tamwil (BMT), Yogyakarta: UII Press Yogyakarta, 2004.

Sarwono dan Yan Pieter Saragih, Membuat Aneka Tahu, Jakarta: Penebar Swadaya, 2001.

Sugiyanto, Analisis Statistika Sosial, Malang: Bayu Media Anggota IKAPI Jaktim, 2004. 
Sugiyono, Metode Penelitian Administrasi dilengkapi dengan Metode $R \& D$, Bandung: ALFABETA, 2007.

Yusuf, Muhammad dan Junaedi, Pengantar Ilmu Ekonomi \& Perbankan Syariah, Jakarta: Ganeca Press.

Zulkifli, Sunarti, Panduan Praktis Transaksi Perbankan Syariah, Jakarta: Zikrul Hakim, 2003. 